\title{
Rancang Bangun Sistem Informasi Perpustakaan Sekolah Berbasis Web Guna Meningkatkan Efektivitas Layanan Pustakawan
}

\author{
Dani Anggoro ${ }^{1}$, Ahmad Hidayat ${ }^{2}$ \\ ${ }^{1,2}$ Program Studi Sistem Informasi, Universitas Budi Luhur \\ dani.anggoro@budiluhur.ac.id ${ }^{1}$, 1612502565@student.budiluhur.ac.id ${ }^{2}$
}

(Received: 16 Mei 2020/ Accepted: 15 Juni 2020 / Published Online: 20 Juni 2020)

\begin{abstract}
Abstrak
Perpustakaan adalah salah satu fasilitas yang dijadikan sebagai penunjang kegiatan belajar para siswa dan guru. Koleksi dari perpustakaan tersebut adalah buku pelajaran yang di jadikan referensi dalam proses pembelajaran. Dalam mengelola data dan informasi, Perpustakaan SMP Negeri 28 Tangerang menggunakan cara konvensional. Cara ini membuat pustakawan kesulitan dalam mengolah data dan menampilkan informasi yang efektif. Tujuan penelitian ini membuat rancang bangun sistem informasi perpustakaan berbasis web untuk membantu pustakawan mengatasi masalah di perpustakaan sekolah. Observasi, wawancara dan studi literature adalah metode yang digunakan untuk mengumpulkan data (analisis kebutuhan). Sementara itu, prototype digunakan untuk membangun sistem informasi perpustakaan sekolah. Hasil rancang bangun sistem informasi perpustakaan sekolah di uji menggunakan black box testing. Hasil penelitian kami yaitu data kegiatan perpustakaan sekolah, rancang bangun sistem informasi perpustakaan sekolah dan hasil evaluasi sistem informasi. Data kegiatan di tampilkan dalam analisa sistem berjalan. Rancang bangun sistem informasi ditampilkan dengan proses bisnis, diagram UML dan tampilan layar dari sistem informasi berbasis web. Hasil dari evaluasi menunjukan bahwa sistem informasi perpustakaan sekolah dapat melakukan penelusuran data secara cepat dan informasi yang di tampilkan dalam bentuk laporan hasilnya akurat.
\end{abstract}

Kata kunci: Perpustakaan Sekolah, Pustakawan, Sistem Informasi

\begin{abstract}
The library is a facility that serves as a support for student and teacher learning activities. The Library's collection is a textbook that is made a reference to the learning process. In managing data and information, the Library of SMP Negeri 28 Tangerang uses conventional way. This makes the librarian difficult to process data and to display effective information. The purpose of this research makes designing a Web-based library information system to help librarians solve problems in school libraries. Observations, interviews and literature studies are methods used to collect data (need analysis). Meanwhile, prototypes were used to build the school library information System. The result of designing the school library information system is tested using black box testing. The results of this system activity's data, designed the school library information System and the results of information system evaluation. Activity Data in the show in system analysis is running. Design builds an information system is displayed with business process, UML diagram and screen view of a web-based information system. The results of the evaluation indicate that the school library information system can perform fast browsing of data and the information shown in the form of reports is accurate.
\end{abstract}

Keywords: School libraries, librarians, information systems

\section{PENDAHULUAN}

Penerapan teknologi informasi pada institusi akan membantu dalam meningkatkan efektivitas kerja pegawainya, sehingga institusi memiliki daya saing serta kualitas kinerja yang baik. Menurut (Mirnasari \& Suardhika, 2018) salah satu hasil pengembangan teknologi informasi yang banyak dimanfaatkan oleh organisasi untuk menjalankan kegiatan 
operasionalnya adalah sistem informasi. Dengan sistem informasi, kecepatan dalam mendapatakan data dan informasi yang dibutuhkan perpustakaan sekolah dalam mengambil keputusan dapat ditingkatkan. Perpustakaan sekolah memiliki pengaruh cukup penting dalam proses belajar mengajar (Hastuti, 2018) meningkatkan prestasi dan motivasi belajar siswa adalah salah satu peran dari perpustakaan, serta dapat memberik layanan kepada pembaca yang ada di sekolah murid, guru, kepala sekolah dan staf administrasi lainnya (Huradju, Saleh, \& Bahsoan, 2020). Dengan fasilitas perpustakaan sekolah, siswa diharapkan memiliki kemampuan dalam mencari suatu informasi secara mandiri. Perpustakaan sekolah yang berada di SMP Negeri 28 Tangerang dalam menjalankan kegiatan proses bisnisnya masih menggunakan cara konvensional atau manual yang mengakibatkan pustakawan kesulitan melakukan penelusuran data dan informasi, adanya resiko kehilangan data serta data menjadi tidak terpusat.

Penerapan teknologi informasi di perpustakaan sekolah dalam bentuk sistem informasi dirasa sangat diperlukan, karena penggunaan sistem informasi dapat meningkatkan efektivitas pustakawan dalam mengelola data dan informasi di perpustakaan sekolah. Menurut (Krismiaji, 2015) Sistem informasi merupakan cara yang teroganisir dalam mengumpulkan, memasukan, mengelola dan melaporkan informasi sehingga mencapai tujuan yang ditentukan. Sedangkan menurut (Siregar, 2002) sistem informasi perpustakaan adalah suatu sistem di dalam suatu organisasi pelayanan publik yang mempertemukan kebutuhan pengolahan transaksi peminjaman, pengembalian dan perpanjangan buku dan pembuatan laporan harian, bulanan maupun tahunan guna mendukung operasi, bersifat manajerial dan kegiatan dari suatu organisasi dan menyediakan pihak luar tertentu dengan laporan-laporan yang diperlukan. Pada penelitian ini dibangun sebuah sistem sistem informasi perpustakaan berbasis web. Web yaitu suatu sistem yang berkaitan dengan dokumen yang dimanfaatkan sebagai media dalam menampilkan teks, gambar, multimedia dan lainnya pada suatu jaringan internet (Sibero, 2013).

Berdasarkan uraian diatas dibuatlah rancang bangun sistem informasi perpustakaan berbasis web yang diimplementasikan pada SMP Negeri 28 Tangerang. Beberapa peneliti sebelumnya telah membuat rancangan dan implementasi sistem informasi diberbagai bidang (Afshar et al., 2019; Mettleq, Soliman, \& Abu-Naser, 2019; Salman \& Abu-Naser, 2019; Steininger, 2019; Yulistina \& Arianti, 2019). Sementara itu yang telah mengembangkan sistem informasi perpustakaan sekolah berbasis web sebagai media yang mengelola data perpustakaan sekolah diantaranya adalah (Lase \& Wijaya, 2018; Mirawati \& Purnia, 2015; Pratiwi, 2018; Puspitasari, 2016; Saputri \& Tanone, 2018). Dalam penelitian tersebut diperoleh informasi bahwa Sistem informasi perpustakaan dapat membantu dan mempermudah pustakawan perpustakaan sekolah dalam mengelola data dan informasi di perpustakaan sekolah guna meningkatkan efektivitas layanan. Perbedaan penelitian ini dengan penelitian sebelumnya adalah pada penelitian sebelumnya belum dibahas proses penambahan buku melalui donasi, fokus penelitian sebelumnya masih di proses peminjaman dan pengembalian buku. Pada penelitian ini, fokus penelitian selain peminjaman dan pengembalian buku, juga akan dibahas pengelolaan data buku hasil donasi sehingga pustakawan dapat memiliki data lebih akurat dan guna meningkatkan efektifitas layanan pustakawan.

\section{METODE}

Protype adalah metode yang untuk merancang dan membangun sistem informasi perpustakaan sekolah. Prototype bukanlah sesuatu yang lengkap, tetapi sesuatu yang harus dievaluasi dan di modifikasi kembali. Dengan menggunakan metode ini pengembang dengan pengguna dapat saling berinteraksi selama pembuatan aplikasi. Dalam mmbangun sisstem perpustakaan sekolah dibutuhkan proses pengumpulan kebutuhan, perancangan dan evaluasi 
prototype (Roger, 2012). Menurut (Khoiriyah \& Manikam, 2019) prototype adalah salat satu metode pengembangan perangkat lunak yang banyak digunakan Dengan menggunakan Metode prototyping ini, pengembangan dan pelanggan dapat saling berinteraksi selama proses pembuatan sistem.

Proses prototype dapat dijelaskan dengan pengumpulan kebutuhan, perancangan dan evaluasi. Pengumpulan kebutuhan dilakukan dengan mempertemukan pengembang sistem dengan pengguna untuk menentukan tujuan umum dan kebutuhan pengguna. Perancangan dilakukan dilakukan secara cepat dan rancangan mewakili aspek aplikasi yang diketahui dan rancangan ini digunakan dalam pembuatan prototype.

Selanjutnya, dalam melakukan pengumpulan data dilakukan dengan observasi dengan cara melakukan pengamatan langsung kegiatan yang berjalan pada perpustakaan sekolah, sedangkan wawancara dilakukan dengan bertanya secara langsung dengan pihak yang terkait dengan kegiatan di perpustakaan (kepala sekolah, pustakawan dan siswa). Sementara itu, studi literatur dilakukan untuk memperoleh data teoritis yang bersumber dari buku dan jurnal ilmiah yang berkaitan dengan sistem informasi perpustakaan sekolah, sehingga dijadikan sebagai pendukung teori dari pembuatan atau rancang bangun sistem informasi perpustakaan sekolah berbasis web (dalam bentuk web).

Evaluasi dilakukan oleh pengguna untuk mengevaluasi prototype yang dibuat dan dipergunakan untuk memperjelas kebutuhan aplikasi. Metode yang digunakan untuk mengevaluasi hasil rancang bangun sistem informasi perpustakaan sekolah adalah black box testing. Black box testing adalah suatu metode untuk menguji software yang telah dibuat dari aspek fungsional tanpa menguji desain interface dan kode program pada aplikasi tersebut. (Sukamto \& Shalahuddin, 2015)

\section{HASIL DAN PEMBAHASAN \\ Hasil \\ Pengumpulan Data}

Berdasarkan metode observasi dan metode wawancara yang dilakukan, penelitian ini mendapatkan data mengenai cara pengolahan data, penyimpanan data dan penyajian informasi dari perpustakaan sekolah, selanjutnya berdasarkan data tersebut, lalu dibahas pada bagian analisa sistem berjalan. Analisa sistem berjalan menjelaskan kegiatan proses bisnis yang ada di perpustakaan sekolah. Hasil yang diperoleh dalam pengumpulan data yaitu pustakawan menjadi aktor utama dalam proses bisnis perpustakaan sekolah, keseluruhan kegiatan yang ada di perpustakaan sekolah masih dilakukan dengan cara konvensional, pencatatan dilakukan pada media kertas dalam bentuk buku catatan, penelusuran data dan pembuatan laporan dilakukan dengan membuka kembali catatan lama. Kegiatan yang ada di perpustakaan meliputi pendaftaran anggota, peminjaman buku, pengembalian buku, donasi buku serta pembuatan laporan yang dibutuhkan.

\section{Perancangan Sistem}

Hasil pengumpulan data selanjutnya dianalisis kemudian dibuat perancangan sistem. Dalam penelitian ini, rancangan sistem informasi perpustakaan sekolah ditampilkan dalam bentuk sistem usulan dan diagram usulan (diagram Unified Modeling Language). Menurut (Pratama, 2014) Unified Modeling Language (UML) merupakan standarisasi internasional untuk notasi yang berbentuk grafik, yang menjelaskan tentang analisis dan desain perangkat lunak yang dikembangkan dengan pemrograman berorientasi objek.

Sistem usulan menjelaskan bagaimana perubahan proses bisnis atau kegiatan yang dilakukan setelah diterapkan sistem informasi perpustakaan sekolah. Perubahan yang terjadi mencangkup bagaimana proses penelusuran data, pencatatan data dan cara menampilkan informasi dalam kegiatan pendaftaran anggota, peminjaman buku, pengembalian buku, donasi buku dan pembuatan laporan yang dibutuhkan. 
Use case diagram meingilustrasikan interaksi yang terjadi antara pengguna dengan sistem yang diusulkan. Dalam diagram tersebut digambarkan aktor yang terdiri dari pustakawan, siswa dan donatur berinteraksi dengan sistem informasi perpustakaan (lihat gambar 1). Sementara itu, Class diagram mengilustrasikan bentuk rancangan data base pada sistem. Menurut (Sukamto \& Shalahuddin, 2015) basis data adalah media untuk menyimpan data agar dapat diakses dengan mudah dan cepat. Diagram tersebut didapatkan berdasarkan hasil dokumen dan analisa proses bisnis (lihat gambar 2).

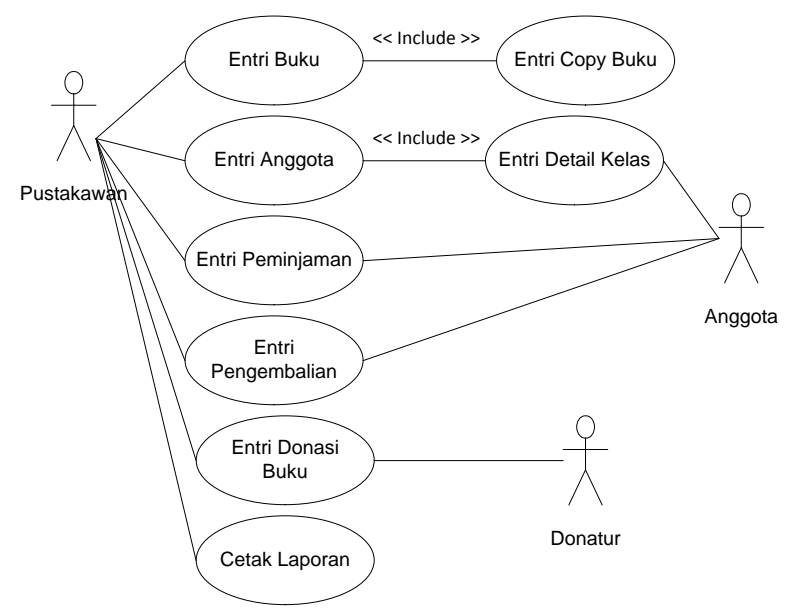

Gambar 1. Use Case Diagram Sistem Informasi Perpustakaan Sekolah

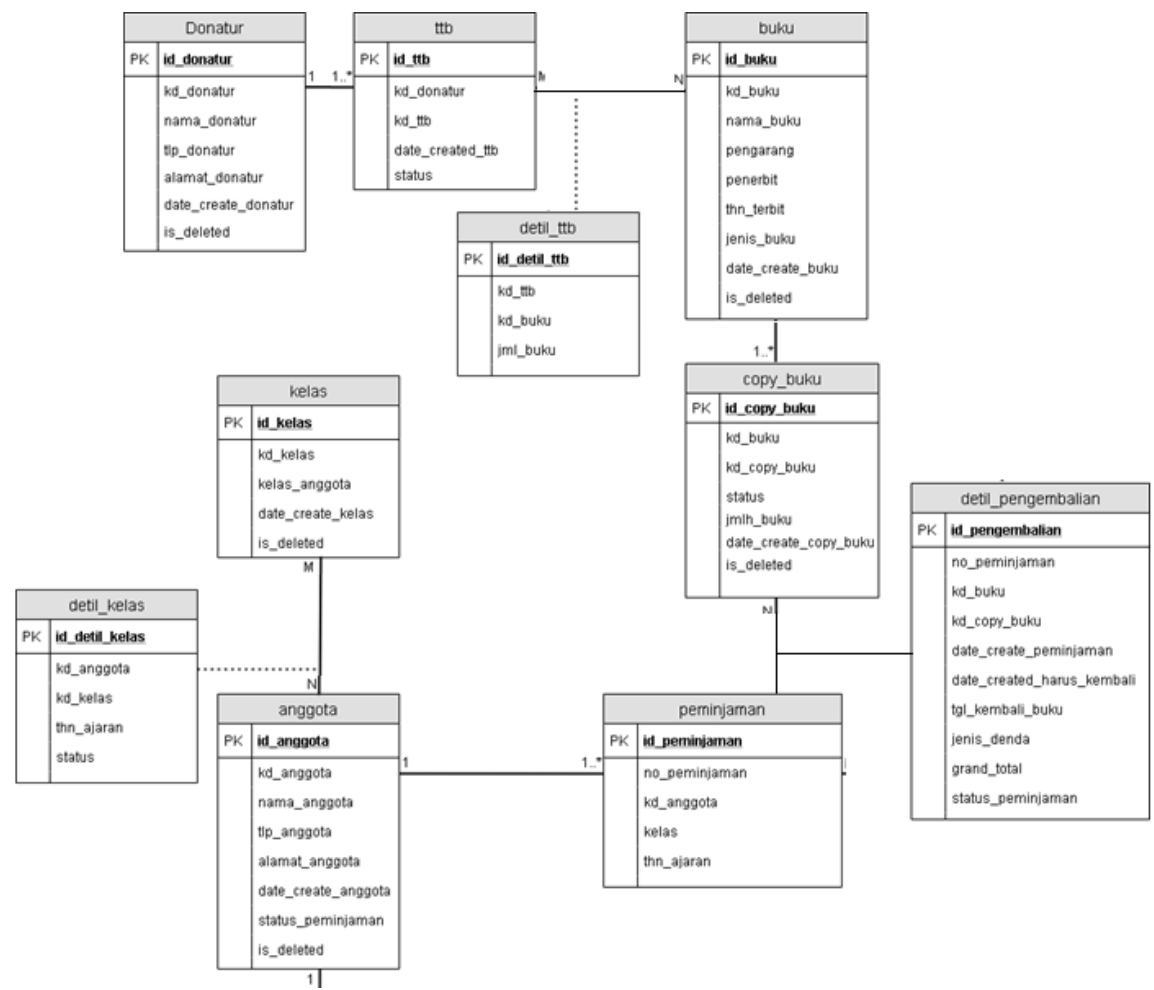

Gambar 2. Class Diagram Sistem Informasi

Perpustakaan Sekolah

\section{Implementasi}

Implementasi sistem perpustakaan sekolah digambarkan dalam bentuk tampilan layar. Sistem informasi yang dibangun berbasis web menggunakan bahasa pemrograman $H T M L$, 
CSS PHP dan JavaScript .Tampilan halaman utama dapat dilihat pada Gambar 3, dimana halaman tersebut menampilkan informasi yang ada di sistem ini. Selanjutnya, tampilan Layar Entri Buku digunakan untuk mengelola data buku yang tersedia di perpustakaan sekolah. Form ini memiliki fitur pencarian untuk menelusuri data buku, menambahkan, mengubah dan menghapus data buku (lihat gambar 4).

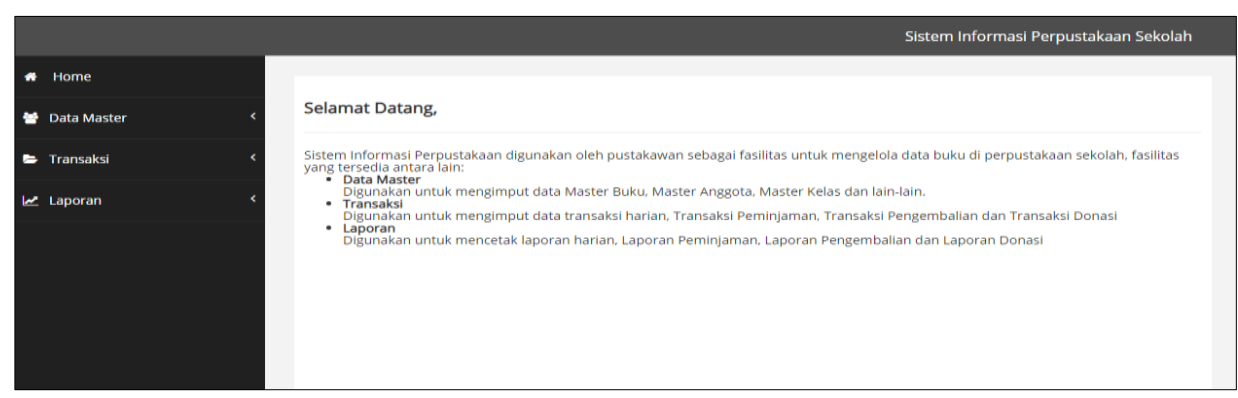

Gambar 3. Halaman Utama

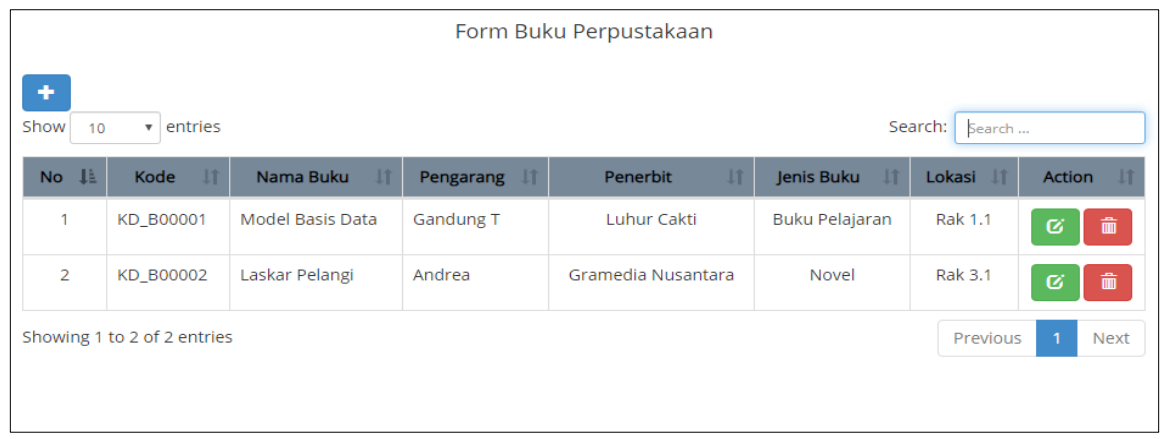

Gambar 4. Entri Data Buku

Layar Entri Peminjaman Buku digunakan untuk mengentri data peminjaman buku. Form ini akan melakukan penelusuran peminjaman buku secara otomatis sehingga pustakawan tidak perlu melakukan penelusuran secara manual, layanan tersebut terlihat pada gambar 5 .

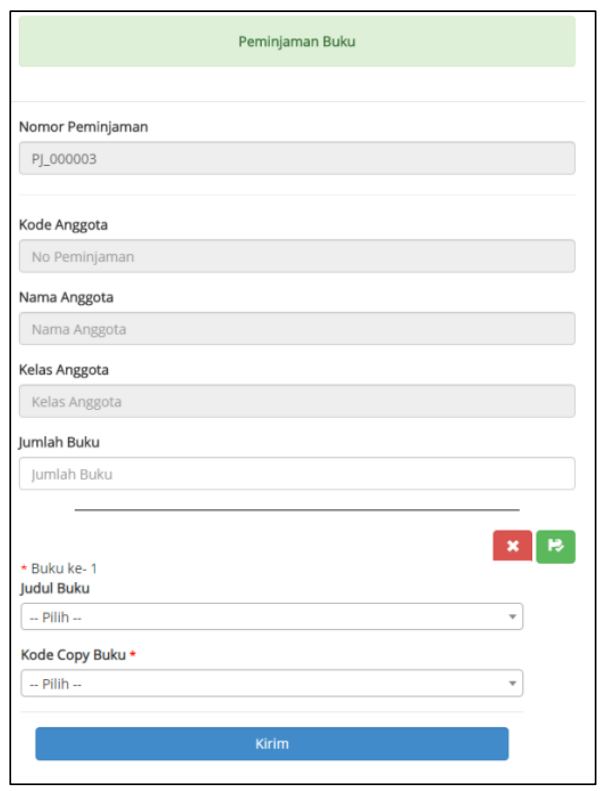

Gambar 5. Entri Peminjaman Buku 
Layar Entri Pengembalian digunakan untuk mengupdate status peminjaman buku yang dilakukan oleh anggota perpustakaan, tampilan Form Pengembalian Buku dapat dilihat pada Gambar 6. Fasilitas yang tersedia pada form ini adalah pencarian data peminjaman berdasarkan parameter yang diinput, informasi keterlambatan dan update status peminjaman

\begin{tabular}{|c|c|c|c|c|c|c|c|}
\hline \multicolumn{8}{|c|}{ Form Pengembalian Buku Perpustakaan } \\
\hline \multicolumn{2}{|c|}{ Show $10 \quad$ entries } & & & Search: & \multicolumn{3}{|c|}{ Search ... } \\
\hline No $\downarrow \mathfrak{l}$ & No Peminjaman it & Anggota & Judul Buku & No. Copy 11 & Sisa Hari $1 \uparrow$ & Actio & It \\
\hline 1 & PJ_000001 & KD_A00001 Andika Pratama & KD_B00002 Laskar Pelangi & CPY_B0005 & 7 Hari & $\approx$ & $\theta$ \\
\hline 2 & PJ_000001 & KD_A00001 Andika Pratama & KD_B00001 Model Basis Data & CPY_B0001 & 7 Hari & $\approx$ & $\theta$ \\
\hline 3 & PJ_000002 & KD_A00003 Reza & KD_B00001 Model Basis Data & CPY_B0005 & 7 Hari & $\approx$ & $\theta$ \\
\hline \multicolumn{5}{|c|}{ Showing 1 to 3 of 3 entries } & Previous & 1 & Next \\
\hline
\end{tabular}

Gambar 6. Form Pengembalian Buku

Layar Entri Donasi Buku digunakan untuk menambahkan data penambahan buku yang bersumber dari donatur. Tampilan Form Donasi buku dapat dilihat pada Gambar 7. Fitur yang terdapat pada form ini adalah pencarian donatur dan penambahan donasi buku.

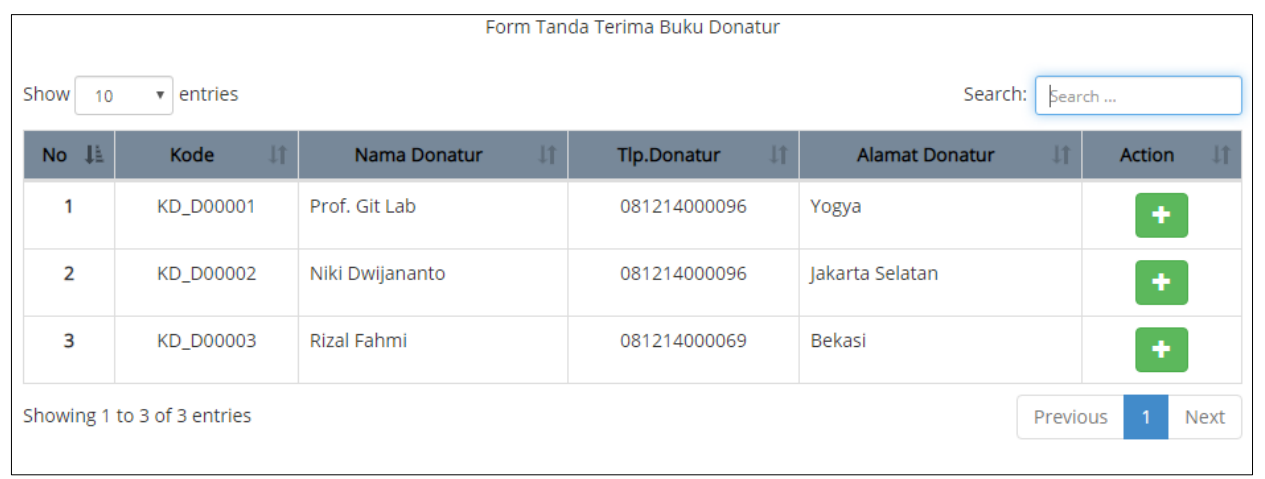

Gambar 7. Form Donasi Buku

Tampilan Layar Laporan Peminjaman merupakan salah satu bentuk keluaran dari sistem informasi perpustakaan sekolah, Tampilan Laporan Peminjaman dapat dilihat pada Gambar 8. Fitur yang terdapat pada laporan ini adalah menampilkan laporan berdasarkan periode.

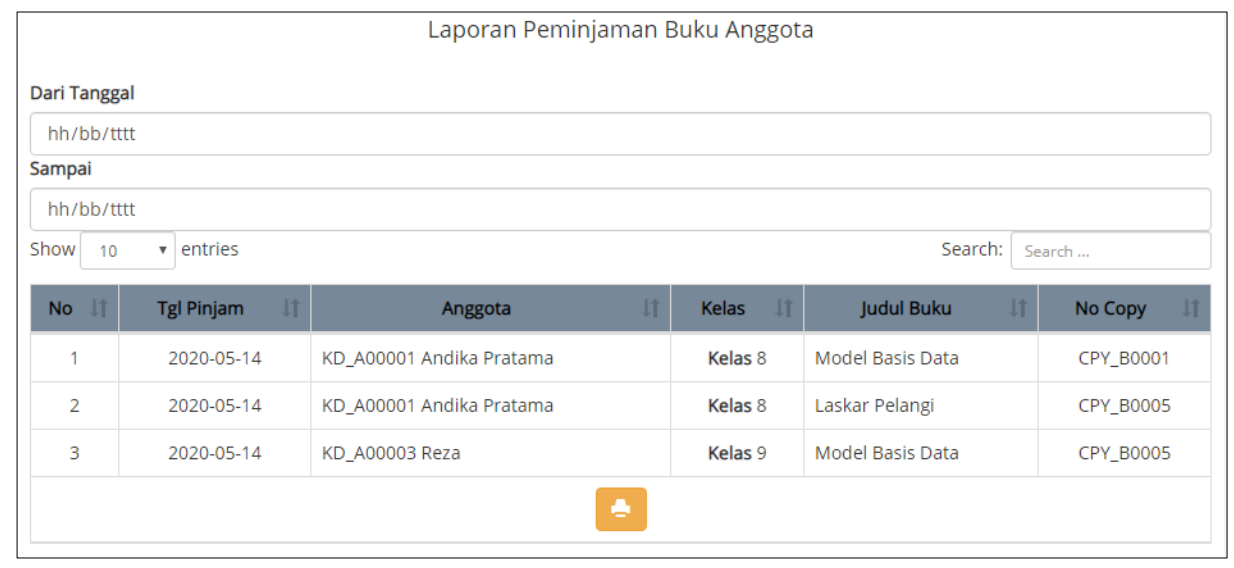

Gambar 8. Laporan Peminjaman 
Tampilan Layar Laporan Donasi digunakan melihat transaksi penambahan buku. Fitur yang terdapat pada laporan ini adalah menampilkan laporan berdasarkan periode donasi (lihat gambar 9).

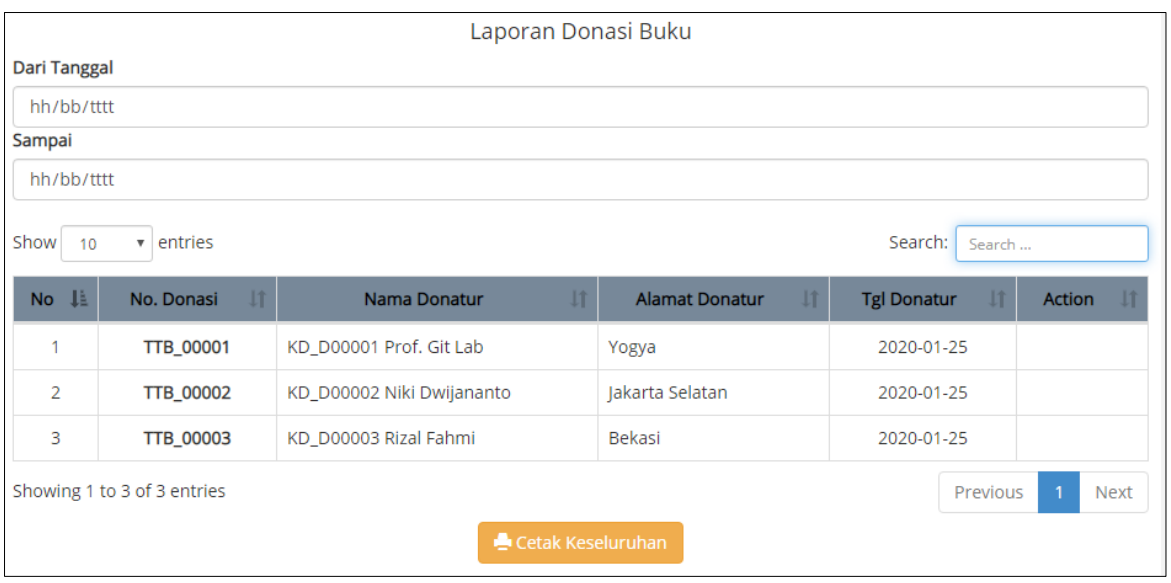

Gambar 9. Laporan Donasi

\section{Evaluasi}

Pada penelitian ini evaluasi dilakukan dengan menguji sistem informasi perpustakaan sekolah menggunakan black box testing yang bertujuan untuk mengetahui sejauh mana keberhasilan sistem informasi yang dibangun. Pengujian melibatkan pustakawan sebagai pengguna sistem. Form yang diuji yaitu form entri buku, form peminjaman, form pengembalian, form donasi, laporan peminjaman dan laporan donasi. Hasil pengujian sistem informasi perpustakaan sekolah menunjukan keberhasilan sistem informasi yang dibangun dalam mempermudah pengelolaan data dan menghasilkan informasi yang efektif dan hasil tersebut nampak pada tabel 1 .

Tabel 1. Rekapitulasi Evaluasi menggunakan Black Box Testing

\begin{tabular}{|c|c|c|c|}
\hline Pengujian & Harapan & Hasil & Kesimpulan \\
\hline $\begin{array}{c}\text { Penelusuran data buku } \\
\text { menggunakan Form } \\
\text { Entri Buku }\end{array}$ & $\begin{array}{l}\text { Menampilkan data } \\
\text { yang sesuai dengan } \\
\text { pencarian }\end{array}$ & $\begin{array}{c}\text { Data yang ditampilkan } \\
\text { sesuai dengan } \\
\text { pencarian }\end{array}$ & Berhasil \\
\hline $\begin{array}{c}\text { Penambahan data buku } \\
\text { menggunakan Form } \\
\text { Entri Buku }\end{array}$ & $\begin{array}{l}\text { Menambahkan buku } \\
\text { otomatis mengupdate } \\
\text { data copy buku }\end{array}$ & $\begin{array}{l}\text { Data copy buku } \\
\text { terupdate otomatis }\end{array}$ & Berhasil \\
\hline $\begin{array}{l}\text { Entri peminjaman } \\
\text { menggunakan Form } \\
\text { Entri Peminjaman }\end{array}$ & $\begin{array}{l}\text { Penelusuran otomatis } \\
\text { histori peminjaman } \\
\text { siswa, menampilkan } \\
\text { peringatan peminjaman }\end{array}$ & $\begin{array}{l}\text { Sistem menampilkan } \\
\text { peringatan anggota } \\
\text { yang belum } \\
\text { mengembalikan buku }\end{array}$ & Berhasil \\
\hline $\begin{array}{l}\text { Entri Pengembalian } \\
\text { menggunakan Form } \\
\text { Pengembalian }\end{array}$ & $\begin{array}{l}\text { Menampilkan informasi } \\
\text { lama peminjaman, } \\
\text { peringatan } \\
\text { keterlambatan }\end{array}$ & $\begin{array}{c}\text { Sistem menampilkan } \\
\text { informasi lama } \\
\text { peminjaman dan } \\
\text { keterlambatan }\end{array}$ & Berhasil \\
\hline $\begin{array}{c}\text { Entri donasi } \\
\text { menggunakan Form } \\
\text { Donasi }\end{array}$ & $\begin{array}{l}\text { Otomatis mengupdate } \\
\text { buku dan copy buku }\end{array}$ & $\begin{array}{l}\text { Data copy buku } \\
\text { terupdate otomatis }\end{array}$ & Berhasil \\
\hline $\begin{array}{c}\text { Cetak laporan } \\
\text { peminjaman } \\
\text { berdasarkan periode } \\
\text { pinjam }\end{array}$ & $\begin{array}{c}\text { Menampilkan informasi } \\
\text { peminjaman yang cepat } \\
\text { dan akurat }\end{array}$ & $\begin{array}{l}\text { Laporan dapat tampil } \\
\text { cepat dan sesuai }\end{array}$ & Berhasil \\
\hline
\end{tabular}


Cetak laporan donasi

berdasarkan periode donasi

\author{
Menampilkan informasi \\ peminjaman yang cepat \\ dan akurat
}

arat

Laporan dapat tampil dan sesuai
Berhasil

\section{Pembahasan \\ Analisa Sistem Berjalan}

Pendaftaran anggota dilakukan oleh pustakawan dengan mencatat data siswa yang mendaftar di buku anggota kemudian pustakawan membuatkan kartu anggota perpustakaan, dan siswa diberikan kembali kartu tersebut. Peminjaman buku dilakukan oleh siswa dengan menyerahkan kartu anggota dan buku yang akan dipinjanjam kepada pustakawan, pada proses ini pustakawan harus mengecek secara manual catatan peminjaman buku yang pernah dilakukan oleh siswa, jika masih ada peminjaman siswa tidak diperbolehkan melakukan pinjaman buku tetapi jika tidak ada peminjaman maka pustakawan mencatat data peminjaman pada buku peminjaman dan kartu buku. Pengembalian buku dilakukan oleh siswa dengan menyerahkan buku yang dipinjam beserta kartu anggota. Pustakawan wajib menelusuri catatan peminjaman buku secara manual, kemudian menghitung lama peminjaman menggunakan kalkulator. Pustakawan juga memeriksa kondisi buku, jika kondisi buku yang dikembalikan rusak dan tidak dapat diperbaiki maka siswa harus mengganti buku yang sejenis. Belum ada catatan penggantian buku di perpustakaan sekolah sehingga mengurangi keakuratan data. Donasi buku dilakukan oleh donatur dengan menyerahkan buku ke perpustakaan sekolah. Proses donasi belum dicatat di perpustakaan sekolah, pencatatan penambahan buku donasi juga belum tersedia, hal tersebut mempengaruhi keakuratan data yang ada di perpustakaan sekolah. Pembuatan laporan di perpustakaan sekolah masih dilakukan secara manual, pustakawan harus mengumpulkan catatan yang terkait dengan kebutuhan laporan, setelah catatan dikumpulkan pustakawan menelusuri data dan mengetikan data tersebut ke microsoft excel. Kegiatan tersebut memakan waktu lama dan laporan yang dihasilkan tidak akurat karena pencatatan data penambahan buku tidak lengkap.

\section{Proses Bisnis Sistem Usulan}

Proses pendaftaran anggota dientri ke dalam sistem, kemudian kartu anggota dicetak berdasarkan data yang di entri menggunakan printer. Pada proses peminjaman, pustakawan dapat mengentri langsung data siswa dan buku yang akan di pinjam menggunakan sistem, pustakawan tidak perlu memeriksa catatan peminjaman karena sistem akan menampilkan peringatan otomatis jika siswa yang meminjam buku masih ada peminjaman buku yang belum dikembalikan. Pada proses pengembalian, pustakawan cukup mengentri nomor atau nama anggota pada sistem. Sistem akan menampilkan informasi lama peminjaman secara otomatis, jika pengembalian tidak terlambat, pustakawan dapat mengubah status peminjaman pada sistem. Jika terjadi keterlambatan pengembalian sistem akan menghitung otomatis denda yang diberikan. Jika ada penggantian buku, sistem akan otomatis mengurangi stok buku, serta pustakawan dapat langsung mengentri buku pengganti menggunakan sistem. Pada proses donasi, disediakan fasilitas untuk mengentri data donasi. Sistem secara otomatis menambahkan stok buku pada database. Sistem juga menyediakan bukti penerimaan buku yang diberikan oleh donatur. Bukti tersebut dapat dicetak dan diserahkan ke donatur sebagai tanda terima yang sah. Pada proses pembuatan laporan, pustakawan dapat menghasilkan informasi dalam bentuk laporan secara cepat dan akurat, pustakawan cukup memilih jenis laporan yang dibutuhkan kemudian mencetak berdasarkan parameter yang dientri.

\section{Donasi Buku}

Kegiatan ini bukan kegiatan rutin yang dilakukan di perpustakaan sekolah tetapi kegiatan ini mempengaruhi data buku yang ada diperpustakaan. Setiap donasi yang diterima seharusnya dientri ke dalam sistem informasi perpustakaan karena akan mempengaruhi stok 
buku maupun copy buku. Hasil dari studi literatur menunjukan bahwa pada penelitian yang dilakukan sebelumnya belum disertakan kegiatan donasi buku. Berdasarkan hal tersebut dalam penelitian ini, rancang bangun sistem informasi perpustakaan sekolah yang dibuat menyertakan proses donasi buku dengan tujuan agak data perpustakkaan lebih akurat. Donasi buku dientri dalam form entri donasi, melalui form tersebut data stok buku dan copy buku terupdate secara otomatis. Laporan hasil donasi ditampilkan dalam cetak laporan donasi. Pustakawan dapat melihat penambahan buku setiap periodenya pada laporan tersebut.

\section{Deskripsi Use Case Diagram}

Interaksi antara pengguna dengan sistem informasi perpustakaan sekolah digambarkan pada gambar 1. Pustakawan dapat menelusuri dan mengelola data buku pada form entri buku. Sebelum menambahkan data buku, pustakawan menambahkan data copy buku. Pustakawan menambahkan data anggota yang diperoleh dari siswa, sebelum menambahkan data anggota, pustakawan mengentri data detail kelas siswa. Pustakawan mengentri peminjaman dengan form entri peminjaman, data peminjaman diperoleh dari siswa, sementara untuk mengembalikan buku pustakawan dapat mengubah status pengembalian pada form entri pengembalian. Pustakawan dapat menambahkan data donasi buku pada form donasi. Pustakawan dapat menampilkan laporan kegiatan perpustakaan menggunakan cetak laporan.

\section{Class Diagram}

Pada gambar 2 terdapat 10 (sepuluh) tabel yang terbentuk, terdiri dari 5 (lima) tabel master diantaranya tabel buku, copybuku, kelas, anggota, dan donator. dan 5 (lima) tabel transaksi antara lain tabel ttb, detil_ttb, peminjaman, detil_pengembalian dan detil_kelas. Data buku disimpan pada tabel buku dan copy_buku. Data anggota disimpan pada tabel anggota, kelas dan detail_kelas. Data peminjaman buku disimpan pada tabel peminjaman, Data pengembalian disimpan pada tabel detil_pengembalian, Data donasi buku disimpan pada tabel ttb dan detail_ttb. Keseluruhan tabel dalam sistem informasi perpustakaan sekolah saling berelasi. Tabel ttb berelasi dengan tabel donatur dan tabel buku. tabel peminjaman berelasi dengan tabel anggota dan tabel copy_buku. Tabel detil_pengembalian berelasi dengan tabel copy_buku dan peminjaman.

\section{Hasil Pengujian}

Hasil evaluasi menggunakan black box testing menunjukan bahwa sistem informasi perpustakaan sekolah dapat melakukan penelusuran data secara cepat, hasil ini didapat dari pengujian form entri buku, form entri peminjaman dan form entri donasi. Sementara pengujian form cetak laporan peminjaman dan laporan donasi menunjukan informasi yang di tampilkan dalam bentuk laporan hasilnya sudah sesuai dengan transaksi yang ada di sistem perpustakaan sekolah.

\section{SIMPULAN}

Rancang bangun sistem informasi perpustakaan sekolah menggunakan metode observasi, metode wawancara dan metode studi literatur untuk pengumpulan data. Metode prototype digunakan untuk membangun sistem. Hasil dari penelitian ini adalah data kegiatan perpustakaan sekolah, rancang bangun sistem informasi perpustakaan sekolah dan evaluasi sistem. Hasil evaluasi menunjukan bahwa sistem informasi perpustakaan sekolah dapat melakukan penelusuran data secara cepat dan informasi yang di tampilkan dalam bentuk laporan hasilnya akurat.

\section{REFERENSI}

Afshar, M., Dligach, D., Sharma, B., Cai, X., Boyda, J., Birch, S., ... Modave, F. (2019). Development and application of a high throughput natural language processing architecture to convert all clinical documents in a clinical data warehouse into standardized medical vocabularies. Journal of the American Medical Informatics 
Association, 26(11), 1364-1369.

Hastuti, B. T. (2018). Kontribusi Kompetensi Pustakawan, Sarana Prasarana, dan Layanan Perpustakaan Sekolah Terhadap Manajemen Mutu Perpustakaan SMA. Media Manajemen Pendidikan, 1(2), 265-276. https://doi.org/10.30738/mmp.v1i2.3251

Huradju, S., Saleh, S. E., \& Bahsoan, A. (2020). Pengaruh Layanan Perpustakaan Sekolah Terhadap Intensitas Kunjungan Siswa Membaca. Aksara: Jurnal Ilmu Pendidikan Nonformal, 5(1), 63-70. https://doi.org/10.37905/aksara.5.1.63-70.2019

Khoiriyah, S., \& Manikam, R. M. (2019). Analisa dan Perancangan Sistem Perhitungan Insentif Marketing Trade Menggunakan Sistem Remunerasi. EDUMATIC: Jurnal Pendidikan Informatika, 3(2), 99-108. https://doi.org/10.29408/edumatic.v3i2.1691

Krismiaji. (2015). Sistem Informasi Akuntansi (4th ed.). Yogyakarta: YKPN Yogyakarta.

Lase, D., \& Wijaya, V. (2018). Sistem Informasi Perpustakaan Pada Sekolah Menegah Atas Negeri 1 Tuhemberua Berbasis Web. Jurnal Armada Informatika, 2(2), 11-22. https://doi.org/10.36520/jai.v2i2.24

Mettleq, A., Soliman, A., \& Abu-Naser, S. S. (2019). A Rule Based System for the Diagnosis of Coffee Diseases. International Journal of Academic Information Systems Research (IJAISR), 3(3), 1-8.

Mirawati, \& Purnia, D. S. (2015). Pembangunan Sistem Informasi Perpustakaan Pada Sekolah Menengah Pertama Negeri 5 Ciamis. Jurnal Informatika Universitas BSI, 2(2), 385-394.

Mirnasari, P. D., \& Suardhika, I. M. S. (2018). Pengaruh Penggunaan Teknologi Informasi, Efektivitas Sistem Informasi Akuntansi, Dan Sistem Pengendalian Intern Terhadap Kinerja Karyawan. E-Jurnal Akuntansi, 23(1), 567-594. https://doi.org/10.24843/EJA.2018.v23.i01.p22

Pratama, A. E. (2014). Sistem Informasi dan Implementasinya. Bandung: Informatika Bandung.

Pratiwi, D., Hartini, S., \& Marlina, S. (2018). Rancang Bangun Sistem Informasi Perpustakaan Pada Sekolah SMK Yadika 13 Tambun Utara Berbasis Web. Jurnal Teknik Informatika Dan Sistem Informasi Paradigma, XX(1), 53-58.

Puspitasari, D. (2016). Sistem Informasi Perpustakaan Sekolah Berbasis Web. Jurnal Pilar Nusa Mandiri, 12(2), 227-240.

Roger, S. P. (2012). Rekayasa Perangkat Lunak Buku (7th ed.). Yogyakarta: Andi.

Salman, F. M., \& Abu-Naser, S. S. (2019). Expert System for Castor Diseases and Diagnosis. International Journal of Engineering and Information Systems (IJEAIS), 3(3), 1-10.

Saputri, Y. S., \& Tanone, R. (2018). Perancangan dan Implementasi Sistem Informasi Perpustakaan berbasis Web (Studi Kasus: SMP Masehi Pekalongan). Jurnal Teknik Informatika Dan Sistem Informasi, 4(1), 87-81. https://doi.org/10.28932/jutisi.v4i1.737

Sibero, F. . A. (2013). Web Programming Power Pack. Yogyakarta: Mediakom.

Siregar, B. (2002). Pengembangan Koleksi. Medan: Badan Perpustakaan dan Arsip Daerah Provinsi Sumatera Utara.

Steininger, D. M. (2019). Linking information systems and entrepreneurship: A review and agenda for IT-associated and digital entrepreneurship research. Information Systems Journal, 29(2), 363-407.

Sukamto, R. A., \& Shalahuddin, M. (2015). Rekayasa Perangkat Lunak Terstruktur dan Berorientasi Objek. Bandung: Informatika.

Yulistina, D., \& Arianti, B. D. D. (2019). E-Katalog Sebagai Sistem Informasi Pemasaran Kopi Sapit Berbasis Web. EDUMATIC: Jurnal Pendidikan Informatika, 3(2), 45-52. 